Vera A. Vratuša Žunjić ${ }^{1}$

University of Belgrade, Faculty of Philosophy,

Department of Sociology

Belgrade (Serbia)
141.82 Луксембург Р.

Original scientific paper

Submitted 01/08/2021

Accepted 20/08/2021

doi: 10.5937/socpreg55-33383

\title{
150 YEARS AFTER THE BIRTH OF ROSA LUXEMBURG: ACTUALITY OF HER SOCIAL REFORM OR REVOLUTION
}

Abstract: The paper examines the actuality of Rosa Luxemburg's Reform or revolution 150 years after her birth.

The main method used is the content analysis of this important polemical pamphlet placed in the context of the time/space, i.e. when and where it was written, on the one hand, and today, on the other.

The main finding is that Rosa's work has remained relevant to our days since the capitalist mode of production is still characterized by internal contradictions producing barbaric consequences of exploitation and imperialist wars. These capitalist system's consequences ensure the permanent actuality of the dilemma between socialism and barbarism confronted by Rosa Luxemburg throughout her life.

Keywords: reform, revolution, capitalism, utopian socialism, scientific socialism, barbarism

\section{Introduction}

The second and the beginning of the third decade of the $21^{\text {st }}$ century characterizes the new period of relative stabilization of the capitalist mode of production since the financial 2007/2008 crisis subsided, especially in the center of the world capitalist economy (Wallerstein, I, 1974). So far, even the current world recession brought about by the economic effects of the COVID-19 world pandemic (cf. Thematic Issue of Sociological Review/Sociološki pregled Society \& COVID-19, 2020), has not disturbed this stabilization substantially. Current apparent political stabilization of capitalism has brought to power mostly center right oriented ideological representatives of the financial bourgeoisie, in contrast to the global political struggles that seemed to be favorable to the Global Left in a first decade of the $21^{\text {st }}$ century.

The members of the movements who, in spite of the mentioned social circumstances have nevertheless remained consistently and strategically oriented towards a structural

1 vera.veritas@gmail.com 
change of exploitative capitalist social relationships, and have not given in to pessimism and inactivity, tend to search for the inspiration and lessons for anti-capitalist revolutionary theory and practice in the life and work of consistent Marxist revolutionaries such as Rosa Luxemburg (1871-1919). Contemporary reexamination of Rosa's work Reform or Revolution (1900, RoR in further text) is a good starting point for drawing the abovementioned lessons in the circumstances of relative stabilization of capitalism. Rosa namely wrote the first five chapters of RoR in similar circumstances at the end of the $19^{\text {th }}$ century - of the apparent absence of the open class fight between the working masses and financial oligarchy in Germany and beyond. RoR is a polemical reaction to and Marxist critique of the theory presented by Eduard Bernstein (1850-1932) in his book The Pre-Conditions of Socialism and the Tasks for Social Democracy (Die Voraussetzungen des Sozialismus und die Aufgaben der Sozialdemokratie, translated to English as Evolutionary Socialism (1899/ Marxist.org. s.a.)).

Rosa was born in a family of Jews in Russian-occupied Poland. The disadvantages like gender, physical disability, Jewish origin, did not stop her from gaining a doctorate at the University of Zurich, becoming a respected academic theorist, journalist, anti-war activist and uncompromising socialist revolutionary who tirelessly questioned those in power (Evans, 2015).

\section{Reform vs. revolution and petite bourgeoisie vs proletariat}

In spite of the title of her work, Rosa Luxemburg insists that she does not contrapose the daily trade union economic struggles and agitation for social reforms and democratization of existing political institutions, which ameliorate the living conditions of the workers, on the one hand, and the final aim - the conquest of political power and the suppression of wage labor, on the other. Rosa agrees that trade union and parliamentary practice are important for raising socialist awareness and consciousness of the proletariat and helping it to organize as a class.

Rosa clarifies that she criticizes Bernstein's proposal to the workers to renounce the social transformation process and to make social reforms the final aim of the class struggle.

Bernstein locates the realization of socialism in the possibility of making the poor rich, in the attenuation of class antagonisms and capitalist crises. Since there can be no socialist movement without a socialist aim, Bernstein ends by renouncing the movement.

In so doing, Bernstein, according to Rosa, reduces the entire labor movement against the capitalist order to a mere effort to repair it. In such proposition Rosa detects Bernstein attempt to ensure predominance of the petty-bourgeois elements within the movement of the working masses that contain its proletarian character. She considers believes that it is of paramount importance that the great mass of workers takes the keen interest in theoretical debates on socialism and gains in such a way "dependable weapons of scientific socialism in their own hands, so that all the petty-bourgeois opportunistic currents, would come to naught" (https://www.marxists.org/archive/luxemburg/1900/reform-revolution/intro.htm).

Rosa insists that the difference between herself and revisionists in SDPG is not in what but in how trade union and parliamentary activity is politically oriented (https://www. marxists.org/archive/luxemburg/1900/reform-revolution/ch05.htm). 
In the following chapters Rosa elaborates mutually interlinked basic topics announced in the Introduction. In the analysis of their content, therefore, it is sometimes not possible to avoid certain repetitiveness that also characterizes Rosa's text, no matter how much as the author of this paper tried to divide different, mutually interlinked topics, into separate sections. An important source of this repetition is of pedagogical nature, keeping in mind that Rosa addresses workers as the reading public, so that the repetition has the function of getting main ideas on socialism and the fight for its realization into the minds of the readers.

\section{Scientific socialism and dialectical method and utopian socialism and opportunist method}

According to Rosa, the basic element of scientific socialism is, first of all, a growing anarchy of capitalist economy, inevitably leading to its ruin. The second element of scientific socialism is the progressive socialization of the production process, which creates the germs of the future social order. The third basic element is the increased organization and consciousness of the proletarian class, which constitutes the active factor in the social revolution.

Bernstein ignores or negates all three mentioned basic elements of scientific socialism. Rosa starts her critique of Evolutionary Socialism by the analysis of the "opportunist method" employed by Bernstein while developing his revisionist theory. The main characteristic of Bernstein's opportunist method is his negation of the very possibility of a transformation to socialism due to general internal contradictions between production and exchange on the capitalist base, ultimately leading to a collapse of capitalism. Since capitalist development does not move, according to Bernstein, in the direction of its own ruin, socialism ceases to be an objectively necessary result of the material development of the society. In this way, Bernstein lifts the program of the socialist movement off its material base and tries to place it on an idealist, utopian base (https://www.marxists.org/archive/luxemburg/1900/ reform-revolution/ch01.htm). ${ }^{2}$

2 In the chapter Economic Development and Socialism (https://www.marxists.org/archive/luxemburg/1900/reform-revolution/ch06.htm) Rosa underlines again that the discovery of grounds of support for the realization of socialism in the economic conditions of capitalist society changed socialism from a utopian ideal into a historical necessity. On the contrary, Bernstein denies the existence of the economic conditions for socialism in the contradictions of capitalism. For Bernstein, socialism has become only a survival of utopianism. He is a former socialist, who has renounced his aim and has decided to find one and immutable goal of human development in the bourgeois society. Bernstein denies the anarchy in capitalist economy and the great general crises due to the contradiction between production and exchange. For Bernstein, Marx's social labor is pure abstraction. He does not acknowledge that abstract human labor, the law of value, the falling rate of profit discovered by Marx as a result of the contradiction between production and exchange and the growth of the productivity of labor have a real social existence in the form of the transitory character of capitalist economy. Exactly because Marx took the socialist viewpoint as a point of departure for his analysis of bourgeois society, he was in the position to give a scientific base to the socialist movement through the dualism of the class antagonism of the bourgeoisie and the proletariat, according to Rosa. 
Opportunism is characterized by hostility to "theory". By theory Rosa means the principles of scientific socialism, which imposes the limitations to aims, means and methods employed in practical activity of the labor movement. Bernstein therefore tried to elaborate a new theory, legitimizing opportunistic currents of action, uniting all opportunist elements at the 1907 Stuttgart Congress of the Second International, pushing the labor movement into bourgeois paths.

Rosa insists that the opportunistic theory that relies on basing socialism on the moral notion of justice, on a struggle against the mode of distribution, instead of basing it on a struggle against the mode of production, the concept of class antagonism as antagonism between the poor and the rich, the effort to graft the "co-operative principle" on capitalist economy, already existed before Bernstein. She adds that after the development of the class struggle and its reflex in social conditions, had led to the abandonment of opportunistic theories and to the elaboration of the principles of scientific socialism. Rosa underlines that there can be no socialism - at least in Germany - outside of Marxist (scientific) socialism. The return to pre-Marxist socialist theories signifies a return to the puny worn-out slippers of the bourgeoisie (https://www.marxists.org/archive/luxemburg/1900/reform-revolution/ch10.htm).

By rejecting Marx's economic doctrine and dialectical method, Bernstein exchanged the scientific base of the working class emancipation for the apologetics of the bourgeoisie, depriving the socialist movement of it class character. Attacking dialectical method Bernstein, according to Rosa, attempts to shatter the intellectual arm with the aid of which the proletariat is enabled to pierce the transitory nature of capitalist yoke, realizing a revolution in the domain of thought (https://www.marxists.org/archive/luxemburg/1900/ reform-revolution/ch06.htm).

To Rosa's mind, the main contradiction of capitalism, as we have seen, exists between the boundless possibilities of the growth of capitalist production, on the one side, and insufficient buying capable demand for produced merchandises on the market, or the crisis of hyper production, on the other (https://w ww.marxists.org/archive/luxemburg/1900/ reform-revolution/ch01.htm). Due to this contradiction, capital wages imperialist wars to annex heretofore non-capitalist societies into the world capitalist market. According to Rosa, the breakdown of capitalism will eventually come, when imperialist bourgeoisie overtakes the last still non-capitalist markets. ${ }^{3}$

The critics of Rosa's book in which she elaborates the main inner contradiction of capitalism leading to its eventual breakdown, The Accumulation of capital (Luxemburg, 1913/online version s.a.), criticize Rosa's main arguments expressed in it due to her overemphasizing the contradictions of the capitalist crisis of hyperproduction in the sphere of exchange and downplaying the capital hyperaccumulation crisis in the production process. The critics claim that the main motive for imperialist expansion is the need not only to open new markets in the still non-capitalist periphery necessary for the realization of produced merchandises, but also to exploit cheaper raw materials and cheaper labor (Bottomore, Harris, Kiernan, Miliband.1983: 293-4). These critics undervalue Rosa's contribution to understanding that imperialist wars present a globalized extension of capitalist exploitation and not just yet another government policy. In his text "Rosa Luxemburg and the actuality or revolution" Paul LeBlanc (Nov. 17, 2019) therefore points out that even when Rosa is partly or largely wrong, her writings are worth comprehending, actively considering, and testing out, as long as determined socialists try to understand and change the world. 


\section{Critique of Bernstein's arguments on the capitalism's capacity of "adaptation"}

The capitalist society, according to Bernstein, has no inner inclination to downfall but, on the contrary, it has the capacity of "adaptation" so that general collapse of the capitalist system of production becomes more and more improbable. Rosa examines these alleged "adaptation" mechanisms of capitalism to the needs of society one by one (credit system"; employers' organizations, cartels and trusts ${ }^{5}$; continuous survival of a "steadfast phalanx" of small and medium-sized enterprises ${ }^{6}$; intensified trade-union and parliamentary activity ${ }^{7}$;

4 A credit system, according to Rosa, constitutes the means of temporary surmounting of private property limits, in order to extend capitalist production through combining a large number of individual capitals in the form of industrial or commercial credit. Far from being a form of adaptation of capitalism, credit at the first symptom of the crisis abandons exchange and reduces to a minimum the consumption capacity of the market. It is thus a mighty instrument for the formation of crises due to the internal contradiction between the almost boundless capacity of production extension, on the one hand, and the restricted consumption capacity of the market, on the other. Credit puts immense productive forces into a small number of hands, thus expropriating large number of small capitalists and leading to speculation with the property of millions of small holders of shares (https://www.marxists.org/archive/luxemburg/1900/reform-revolution/ch02.htm). Credit therefore constitutes an indispensable gear in the mechanism of contradictory capitalist economy like money or the market. It is simultaneously an instrument of capitalist economy's destruction, since it aggravates the internal contradictions of capitalism (https://www.marxists. org/archive/luxemburg/1900/reform-revolution/ch05.htm).

5 Employers' organizations, cartels and trusts, according to Rosa, are not capable either of ending the anarchy of capitalist production through regulation, as Bernstein suggests, since they are not and cannot be the dominant form of entire capitalist production. They present the social character of capitalist production and tend to increase the rate of profit in one branch of industry at the expense of another, but cartels cannot be generalized. By keeping inactive a part of the accumulated capital, they sharpen the crisis and competition for consumers on the foreign markets which will sooner or later become exhausted. Cartels also aggravate the exploitation of labor and augment antagonism between capital and labor to the extreme (https://www.marxists.org/archive/luxemburg/1900/reform-revolution/ch04.htm).

6 Continuous existence of a "steadfast phalanx" of small and medium-sized enterprises constitutes, according to Rosa, the pioneers of technical change who find themselves under the influence of two antagonistic tendencies: the periodic depreciation of the existing capital, on the one hand, and continued rise of the scale of production and increase of the minimum amount of capital necessary for the functioning of the enterprises in the old branches of production, on the other (https:// www.marxists.org/archive/luxemburg/1900/reform-revolution/ch02.htm). Bernstein forgets the necessity of new placements of small and medium-sized capital during circular crises. Because of that small capital constantly reappears which seems to Bernstein to be the sign of the cessation of capitalist development, even though it is the symptom of normal capitalist development through cyclic crises (https://www.marxists.org/archive/luxemburg/1900/reform-revolution/ch05.htm). Bernstein fails to notice that average foundation capital of shareholder societies has diminished, indicating socialization not only of large but also of medium-sized and small production. Shareholding stands for the separation of production from capitalist ownership on a capitalist base.

7 Trade unions, according to Rosa, cannot give the workers a determining influence over production, neither its dimensions nor technical progress. The law of wages is not shattered but applied by 
social protection labor legislation"; "co-operative principle" $)$, and demonstrates that they in fact deepen the contradictions of capitalism.

Rosa concludes that there cannot be any expropriation of the means of production by stages on the basis of progressively more extensive control over the conditions of production through trade union struggle and political reforms, which would, according to Bernstein, gradually reduce the rights of proprietors to the role of their simple administrators. The big capitalists, according to Rosa, on the contrary, became big shareholders separated from any personal relation with administration of production (https://www.marxists.org/archive/ luxemburg/1900/reform-revolution/ch03.htm).

trade union activity. Trade unions are nothing more than the organized defense of labor power against the attacks of profit. The share of the social wealth going to the working class is reduced with the fatality of a natural process by the growth of the productivity of labor and the situation of the labor-power market due to proletarization of the middle strata of the society (https://www. marxists.org/archive/luxemburg/1900/reform-revolution/ch07.htm).

The function of trade unions consists in providing the workers with a means of realizing the capitalist law of wages, the sale of their labor power at current market prices, depending on the conjuncture of labor demand and supply and the degree of productivity of labor. Trade unions, however, cannot suppress the law of wages, exploitation and influence the process of production itself. Since the reduction of wages is one of the principal means of retarding the tendency of the profit to fall, trade union action is reduced to the simple defense of already realized gains. Rosa concludes that therefore the political side of the class struggle must be developed.

According to Rosa, Bernstein directs the entire activity of trade unions toward the further amelioration of the economic and political situation of the proletariat through wages bargaining, co-operation and parliamentary elections.

Rosa sums up that due to Bernstein's considering trade union and parliamentary activity as tools of the direct socialization of capitalist economy, this activity in fact loses its effectiveness reduced to an end in itself. It does not lead to the final goal of socialism, but moves in an exactly opposite direction. This activity thus ceases being instrument of preparing the working class for the conquest of power. Socialist democrats should on the contrary encourage the workers to realize the impossibility of accomplishing a fundamental social change just through trade union and parliamentary activity and that the conquest of power is unavoidable.

8 Unlike Bernstein, Rosa does not see social protection labor legislation, as a piece of "social control" and socialism. Namely, the state is not a "society" representing the "rising working class", but a class organization representative of capital (https://www.marxists.org/archive/luxemburg/1900/ reform-revolution/ch03.htm).

9 According to Rosa, Bernstein transforms socialism from a definite historical phase of social development into an abstract "co-operative principle". Economic democracy and co-operatives (https:// www.marxists.org/archive/luxemburg/1900/reform-revolution/ch07.htm) will allegedly suppress industrial progressively profit and commercial profit in the field of production, suggesting that there are no antagonistic classes in capitalist society, recognizing the bourgeoisie as the champion of the general interest of humanity, preaching to the working class the quintessence of the morality of the bourgeoisie, that is, reconciliation with the existing social order. Rosa reminds readers that pitiless exploitation in capitalist economy becomes a condition for the survival of each enterprise. The workers forming a co-operative are obliged to take toward themselves the role of an exploiting capitalist entrepreneur so that cooperatives either become pure capitalist enterprises competing on the market, or end by dissolving, if they are not backed by consumers' organizations. They are excluded from the most important branches of capital production. The establishment of producers' cooperatives on a wide scale would suppose the suppression of the world market. 


\section{The capitalist state, parliamentarism and the conquest of democratic political power}

Rosa elaborates her views on the state as a class organization of capital, underlining that capitalist development makes state intervention and control in the society more and more necessary. But the state in capitalism remains an organization of the ruling class implementing the policy of tariffs, militarism and colonial imperialism. Parliamentarism thus expresses a society in which capitalist interests predominate. It is therefore an illusion of reformists that the contradiction between the class state and society is to be liquidated through increased state control and the progress of democracy. Rosa is certain that only the conquest of political power by the proletariat can realize democracy necessary and indispensible to the working class for autonomous administration in the task of transforming the bourgeois society (https://www.marxists.org/archive/luxemburg/1900/reform-revolution/ch04.htm).

Bernstein presents socialism not as a consequence of economic compulsion but as a result of the feeling of justice and will, as well as of the growth of democracy. Rosa demonstrates that no absolute and general relation can be constructed between capitalist development and democracy. Democratic institutions have completely exhausted their function as aids in the development of bourgeois society. Liberalism has even begun to be an impediment to capitalism due to world politics and the aggravation of competition on the world market and the strengthening of the labor movement. The fate of democracy is bound up with the fate of the labor movement. Realization of democracy requires a conquest of political power by the working masses (https://www.marxists.org/archive/ luxemburg/1900/reform-revolution/ch08.htm).

In her important political pamphlet Russian Revolution (1918/1999) Rosa simultaneously notices the limits of representative democracy, but also demands that the revolution promotes representative democracy. In chapter four she criticizes Lenin (1870-1924) and Trotsky (1879-1940) for having abolished the elected Constituent Assembly immediately after the October Revolution ${ }^{10}$. Rosa concludes in a famous slogan that freedom is always the freedom for those who think differently. Her critique of representative democracy prevents us from interpreting this slogan as the demand for indiscriminate general tolerance.

From the revisionist standpoint, Rosa demonstrates, the conquest of power is simultaneously impossible and useless. Socialism allegedly can be introduced only as a result of the trade union and parliamentary activity. According to revisionists, these activities have a socialist character because they supposedly exercise a progressively socializing influence on capitalist economy.

In contrast, Rosa argues that such socializing influence is purely imaginary, since trade union and parliamentary activities are in practice carried out only for their immediate results of instantly improving the present situation of the workers. In Bernstein's revisionist

10 "To be sure, every democratic institution has its limits and shortcomings, things which it doubtless shares with all other human institutions. But the remedy which Trotsky and Lenin have found, the elimination of democracy as such, is worse than the disease it is supposed to cure; for it stops up the very living source from which alone can come correction of all the innate shortcomings of social institutions. That source is the active, untrammeled, energetic political life of the broadest masses of the people" (https://www.marxists.org/archive/luxemburg/1918/russian-revolution/ch04.htm). 
Vera A. Vratuša Žunjić, 150 years after the birth of Rosa Luxemburg: Actuality of her Social...

theory and practice they lose all connection with political work for socialism, since they exclude the preparation of the proletariat, subjective factor of the socialist transformation, for the task of realizing socialism (https://www.marxists.org/archive/luxemburg/1900/ reform-revolution/ch05.htm).

Marginalist, vulgar and mechanical bourgeois economic theory

Bernstein's marginalist and mechanical economic theory constitutes the second point for which Rosa criticizes Bernstein's theory and method. According to this theory, the capitalist is seen as an isolated entrepreneur who reflects in his mind the economic facts around him just as they appear when refracted by the laws of competition. The isolated capitalist sees each organic part of the whole of capitalist economy (credit, money, market, cartels, small and medium enterprises...) as an independent entity. He sees them as they act on him, the single capitalist especially during crises. For the isolated capitalist, crises are really simple derangements while the cessation of crises accords him a longer existence. As far as the single capitalist is concerned, a credit, for instance, is only a means of "adapting" his insufficient productive forces to the needs of the market. Therefore, it seems to him that the cartel of which he becomes a member really suppresses industrial anarchy (https:// www.marxists.org/archive/luxemburg/1900/reform-revolution/ch05.htm).

Marginalism ends up in a utopia and a program of reaction. Rosa defines the theory of revisionism as a theory of standing still in the socialist movement, built on a theory of capitalist standstill (https://www.marxists.org/archive/luxemburg/1900/reform-revolution/ch05.htm).

In contrast to Bernstein's marginalist economic theory, according to which "capitalist" is not an economic unit, or a factor of production, but a fiscal unit, a certain quantity of money, Rosa insists that the industrial capitalist represents a collective person composed of hundreds and even thousands of individuals.

Rosa sums up that revisionism is nothing else than a theoretic generalization made from the angle of the isolated capitalist, that is from the viewpoint of vulgar bourgeois economics. All the errors of bourgeois economics rest precisely on the conception that mistakes the phenomena of competition, as seen from the angle of the isolated capitalist, for the phenomena of the whole of capitalist economy. This vulgar economics tries to find the antidote against the ills of capitalism in the phenomena of capitalism. The vulgar economist believes that it is possible to regulate capitalist economy and to palliate the contradictions of capitalism.

\section{Attenuation of class antagonisms, crises and the petty bourgeois renunciation of a socialist aim}

In accordance with his claim concerning the adaptability of the capitalist mode of production and exchange, Bernstein interprets capitalist crises as simple derangements of the economic mechanism. Namely, he believes that with cessation of crises, the capitalist mechanism could function well. On the contrary, Rosa underlines that crises are not "derangements" in the usual sense of the word: crises are "derangements" without which 
capitalist economy could not develop at all. In fact, crises constitute the only normal method possible in capitalism of solving periodically the conflict existing between the unlimited extension of production and the narrow limits of the world market. Crises are therefore an organic manifestation inseparable from capitalist economy. Due to a periodic depreciation of capital, crises bring a fall in the prices of means of production, a paralysis of a part of the active capital. In time there comes an increase in profits, which thus create the possibility of the renewed advance of rekindling the fire of capitalist development.

In the chapters of RoR which she edited after the experiences of revolution in Russia in 1905 and later, Rosa also points out that hardly had Bernstein developed his argument of the "adaptation" of the capitalism through the credit system, cartels and trusts, when a profound general commercial crisis broke out in 1907/8, exactly in the countries which had the greatest development of credits and trusts (https://www.marxists.org/archive/ luxemburg/1900/reform-revolution/ch02.htm).

Rosa concludes that the anarchic capitalist production cannot "adapt" itself to exchange and thus become a durable production system since the world market cannot spread unlimitedly (https://www.marxists.org/archive/luxemburg/1900/reform-revolution/ch05. htm). Sooner or later the world market will be extended to its limit and become exhausted through the competition of the capitalist countries (https://www.marxists.org/archive/ luxemburg/1900/reform-revolution/ch02.htm) (cf. FN ii).

Rosa claims that socialism will be the consequence of 1) the growing inner contradictions of capitalist economy becoming ever sharper instead of disappearing and 2) of the comprehension by the working class of the unavoidability of the suppression of these contradictions through a social transformation. Since revisionism denies the first contradiction and rejects the second, it reduces the labor movement to a simple reformist movement which abandoned the class viewpoint of the working class and becomes the standpoint of the capitalist apologist.

\section{Utopianism and reactionarity}

Rosa reveals Bernstein's theory as both utopian and reactionary. Rosa reiterates in the first place that a defective, crisis-ridden capitalist development cannot lead to a socialist transformation since neither the credit system nor cartels and survival of the middle class can be regarded as "means of adaptation" of capitalist economy, in spite of the temporary cessation of crises, which always erupt again in an ever sharper form.

According to Rosa, Bernstein renounces the struggle against the capitalist mode of production and attempts to direct the socialist movement to struggle toward more just "distribution". Since the mode of production is the cause of the mode of distribution, Social Democracy should struggle for the suppression of the capitalist production itself.

Bernstein sees the legislative course of historical development as the action of methodical "intelligence" while for him the revolutionary course of historical development is the action of a spontaneous "feeling". In the history of bourgeois society, according to Rosa, legislative reform served to strengthen progressively the rising class till the latter was sufficiently strong to seize political power, to suppress the existing judicial system and to construct a new one itself. 
Rosa summarizes $R o R$ in the famous slogan: "Legislative reform and revolution are not different methods of historical development that can be picked out at pleasure from the counter of history, just as one chooses hot or cold sausages. Legislative reform and revolution are different factors in the development of class society. They condition and complement each other, and are at the same time reciprocally exclusive, as are the north and south poles, the bourgeoisie and the proletariat". People who pronounce themselves in favor of the method of legislative reform in place and in contradiction to the conquest of political power and social revolution, do not really choose a more tranquil, calmer and slower road to the same goal, but a different goal. Instead of taking a stand for the establishment of a new society they take a stand for surface modifications of the old society, suppression of the abuses of capitalism instead of suppression of capitalism itself" (https://www.marxists. org/archive/luxemburg/1900/reform-revolution/ch08.htm) .

Rosa stresses that legislative reform of capitalism is not possible since the class domination within it does not rest on "acquired rights" but on real economic relations of domination of capital over labor understood as merchandise possessing the quality of producing surplus value, greater than the value it consumes. Therefore wage slavery cannot be suppressed in the "legislative way".

Bernstein warns the proletariat against the danger of acquiring political power too early. Behind this stance Rosa detects the belief that the socialist program is unrealizable and expresses general opposition to the aspiration of the proletariat to possess itself State power ${ }^{11}$.

Rosa claims that the seizure of power presupposes a definite degree of maturity of economic and political relations and a large conscious popular class as the product of the decomposition of bourgeois society. The socialist transformation presupposes a long and stubborn struggle, in the course of which, the proletariat will be probably repulsed more than once. These "premature" attacks of the proletariat constitute a very important factor creating political conditions to maintain the political power for good.

\section{Opportunism in Theory and Practice}

Rosa demonstrates that opportunism appeared as a clearly defined current in the German labor movement with the suppression of the anti-Socialist laws in 1887 (which authorities introduced in 1881 in fear of the rapid increase in numbers and organization of workers movement) (https://www.marxists.org/archive/luxemburg/1900/reform-revolution/ch10.htm).

11 In Rosa's book RoR, so-called "state-centered" political culture can be detected when she insists, like Lenin and Trotsky, in contrast to Bernstein, on the necessity of workers seizing state power. Some indigenous peoples, like Zapatistas in Mexico, react with non-violent and non-armed self-defense, building the areas of health and education, infrastructures, Indigenous Guard without arms. This is grounded presence of the community where people rely on one another and only have their bodies to defend themselves in their autonomous zones with barter fairs. They choose to be non-violent because they do not want to replicate the violence of the state (Zibechi, R. 2021, May 21). The problem is in the fact that governments of respective countries often do not allow the indigenous people to build peacefully their own autonomous common social infrastructure, encroaching into the indigenous people's communities with their extractive and urbanization projects that dispossess local communities from their land. 
The Social-Democratic movement, Rosa emphasizes, must grope on its road of development between the following two rocks: abandoning the mass character of the party or abandoning its final aim falling into bourgeois reformism or into sectarianism, anarchism or opportunism. Because social democratic movement is a mass movement and because the dangers menacing it are not derived from the human brain but from social conditions, Marxist doctrine could not insure us, in advance and once for all, against the anarchist and opportunist tendencies.

Rosa underlines that the surprising thing is not the appearance of an opportunist current in the last decade of the $19^{\text {th }}$ century, but rather its feebleness, since in it there is not a shadow of the original thought: "Not a single idea that was not refuted, crushed, reduced into dust by Marxism several decades ago! Only dialectics and the materialist conception of history ... could make Bernstein appear as an unconscious predestined instrument, by means of which the rising working class expresses its momentary weakness but which, upon closer inspection, it throws aside contemptuously and with pride (https://www.marxists. org/archive/luxemburg/1900/reform-revolution/ch10.htm).

\section{Conclusion}

With her RoR pamphlet, Rosa's achievement in the first decade of the $20^{\text {th }}$ century was that Karl Kautsky (1854-1938), the most authoritative Marxist theoretical figure in the Second International, at the least paid lip service to the socialist goal during SPD and Second International conferences. However, when all parliamentarians, including SPD members, on voted for war credits on $4^{\text {th }}$ August 1914, they betrayed the working class and the final aim of transition to socialism, enabling and even encouraging the entrance of Germany into the barbaric imperialist World War ${ }^{12}$.

12 In the first chapter of her Junius Pamphlet (Luxemburg: 1915b/1996) Rosa Luxemburg attributes the famous dilemma "socialism or barbarism" to Friedrich Engels (1820-1895; cofounder of the "scientific socialism" with Karl Marx (1818-1883); Vratuša, 2020b). Rosa did not cite the precise source, since she wrote this pamphlet in prison: "Bourgeois society stands at the crossroads, either transition to socialism or regression into barbarism." Rosa continues by elaborating the meaning of this dilemma in then actual historical context: "What does 'regression into barbarism' mean to our lofty European civilization? ... This world war is a regression into barbarism. The triumph of imperialism leads to the annihilation of civilization. At first, this happens sporadically for the duration of a modern war, but then when the period of unlimited wars begins, it progresses toward its inevitable consequences. Today, we face the choice exactly as Friedrich Engels foresaw it a generation ago: either the triumph of imperialism and the collapse of all civilization, as in ancient Rome, depopulation, desolation, degeneration - a great cemetery, or the victory of socialism, which means the conscious active struggle of the international proletariat against imperialism and its method of war. This is a dilemma of world history, an either/or; the scales are wavering before the decision of the class-conscious proletariat. The future of civilization and humanity depends on whether or not the proletariat resolves manfully to throw its revolutionary broadsword into the scales. In this war imperialism has won. Its bloody sword of genocide has brutally tilted the scale toward the abyss of misery. The only compensation for all the misery and all the shame would be if we learn from the war how the proletariat can seize mastery of its own destiny and escape the role of the lackey to the ruling classes" (Luxemburg, 1915b/1996, www.marxists.org/archive/luxemburg/1915/junius/ch01.htm). 
The defeat in the Great War in 1918 sparked off revolutionary turmoil among workers in Germany. Rosa and Karl Liebknecht hailed the revolutionary tactics for extra-parliamentary mass action, semi-spontaneous mass strikes which broke out in revolutionary situations of extreme oppression and/or imperialist war exhausting efforts (Rosa, 1905), until the first successes strengthened and raised self-confidence of the workers. Historical events overcame Rosa's suggestions from the time of stabilization of capitalism that trade union fights should have a revolutionary component (like the demand for ownership of enterprises and decision making by the workers what, where, how and how much to produce and distribute, for instance), since the capitalist system can undo each partial reform at any time, as it happened with Roosevelt’s (1882-1945) "New Deal” or Tony Blair's (1953- ) “Third Way".

The foundation of the German Communist Party in 1918, however, was too late to win over the majority of the working class to a revolutionary Marxist orientation during the revolutionary rebellion in Germany. During this period of revolutionary turmoil in Germany, social democrats headed by Friedrich Ebert (1871-1925) came to power without any intent to proceed towards the transition to socialism. Instead, they ordered the summary execution of Rosa Luxemburg, Karl Liebknecht and other communists. They accused the communists of endangering the constitutional order during the Spartacist uprising in Berlin in January 1919. Rosa and Karl considered this uprising a blunder (Hettman, 1980:308), but did not hesitate to support the attempted overthrow of the government. As a matter of fact, they were aware that the critical mass of workers in other parts of Germany had not rebelled.

The opportunistic leaders of one of the most numerous social democratic parties crushed the communist uprising by sending in the Freikorps, government-sponsored paramilitary troops consisting mostly of World War 1 veterans. These death squads ${ }^{13}$ captured and summarily executed Rosa, Karl and other communists, confirming the existence of deep cleavages between the revolutionary and reformist wings of the widely understood left-oriented movements.

In her last text, Order Prevails in Berlin (January 1919/1999), in spite of the failure of the November 1918 revolution, Rosa as a true revolutionary exclaims: "You foolish

In 1918 Rosa sharpens her conclusion from RoR about the Second International, claiming that it was already inherently a decaying corpse and that the success of reformist gradualism in transforming capitalism in an evolutionary manner is impossible.

In the face of the bourgeois opportunism and betrayal of German SDP, during WW1 Rosa Luxemburg, Karl Liebknecht (1871-1919), Clara Zetkin (1857-1933) and others co-founded the anti-war and anti capitalist Spartacus League (Spartakusbund) which they transformed into the Communist Party of Germany and joined the Third Communist International (COMINTERN) in 1919.

13 Today n many countries, especially in Latin America, state violence still coexists with paramilitaries, very much resembling the Freikorps in Germany after WW1, which killed Rosa Luxemburg, Karl Liebknecht and other communists. In Columbia, for instance, state and paramilitary violence led by the militarist criminal government of Iván Duque Márquez, provoked a general strike on 29th April 2021. On May Day, hundreds of thousands of indigenous and black peoples took to the streets, mostly young who had conquered fear. The government responded to protests with an unprecedented use of violence, killing dozens of demonstrators, as if their lives did not matter, like the lives of people in quasi-apartheid countries, Palestinians in Israel and Gaza, indigenous peoples in Columbia, black people in the USA, or the Maghreb people in France, whenever capital exercises its crime against the peoples and environment (Zibechi, R. 2021, May 21). 
lackeys! Your 'order' is built on sand. Tomorrow the revolution will rise up again, clashing its weapons, and to your horror it will proclaim with trumpets blazing: I was, I am, I shall be!" (https://www.marxists.org/archive/luxemburg/1919/01/14.htm).

Rosa was right that the SDP leadership, insisting on election victories and participation in a bourgeois parliament, obviously did not find a peaceful route to socialism. On the contrary, it paved the way for the most reactionary counterrevolution ever seen two decades later - national socialism. We should not delude ourselves that such events from the past are no longer possible due to contemporary constitutions defending democratic institutions (Gürgen: 25/01/2019).

\section{On the inevitability of the final crisis of capitalism once again}

Rosa Luxemburg's insists on the inevitability of the final crisis of capitalism in accordance with Marxist theory as she interpreted it, in contrast to Bernstein and revisionists, who claim that capitalism has adapted enough to be able to avoid crises. We have seen that some commentators criticize Rosa Luxemburg for economic determinism and political fatalism when she writes about the inevitability of the breakdown of capitalism. This is, however, rather one-sided criticism. Namely, Rosa repeatedly insists that social democrats should not wait for the antagonisms of capitalism to develop into a final crisis, but should constantly agitate among working masses, helping long term orientation of the spontaneously arising mass strikes with new modalities of self-organization like assemblies and soviets. Thus, left parties are not an end in themselves and if reformist parties without revolutionary commitments become an obstacle to revolutionary activity of the masses, they must be replaced with revolutionary ones.

Rosa's apparent fatalism can be explained as the need of revolutionaries to endure and persevere in their aim to throw off the capitalist mode of production by revolutionary means of mass strike and armed takeover of political power, in the conditions of stabilization of capitalism under the reactionary military, conservative or reformist social democratic governments.

The absence of insistence of opportunist social democrats on the tendency of capitalism to go through ever more devastating crises comes down to Bernstein's argument that capitalism has adapted enough to avoid the final crisis and therefore that it presents an eternal mode of production. It is exactly when reformists like Bernstein conclude on the basis of a longer period of quasi absence of crises and class fight that capitalism is no longer prone to crises, crises erupt again and again, due to the resistance of the oppressed classes to the profit-seeking accumulation by dispossession policies of the ruling classes, ever since the so-called primitive accumulation (Marx, K. 1977:t.21, 630-682; Harvey, 2004).

The present period of apparent stabilization of capitalism at the same time is fraught with the contradictions and imperialist war threats within the epoch of the historical succession of the hegemonic power in the world system of capitalist economy (Wallerstein, 1974). The new hegemonic order seems to be shifting over to Asia, especially focused on China $^{14}$ (Naughton: 2014; Vratuša, 2018b) .

14 So far the rise of China has not relied on a massive war economy but the present ruling classes of the declining hegemonic power, the USA, will probably refuse to step down from this position without resistance. In the context of the actuality of Rosa's RoR and her preoccupation with the transition from capitalism to socialism, many commentators point out that China is not a socialist 
Let us remember that Marx and Engels stressed that the result of the permanent class struggle between the exploited and exploiting class ended each time either in a revolutionary reconstitution of the society at large, or in the common ruin of the contending classes (Marx, Engels. 1848/2010:32; Vratuša, 2018b).

More than a hundred years after Rosa wrote RoR and the Junius Pamphlet, there no longer exist the revolutionary social context and substantial global labor movement, profoundly influenced by the theory of historical materialism, with an influential left wing infused with the sense of the actuality of revolution. Rosa Luxemburg is right in underlying that "we can only grow through struggle, and it is in the middle of struggle where we learn how to fight" in the actual struggles of today and tomorrow ${ }^{15}$.

James Peron (June 1,2000) claims that there is no reason to think that if we follow the advice of today's reformist socialists, which led to self-destruction in Greece, France and Spain, we will end up with anything much different to the kind of barbaric carnage that overtook Europe from 1914 onwards. Nothing fundamental has changed about capitalism in the intervening period. Like Rosa, Peron claims that capitalism's tendency to fall into crises remains. In fact, the crises are deepening and proliferating. If imperialist tensions between China and the USA were, at some point in the coming decades, to break out into a direct military conflict, the consequences for humanity would be even more devastating than in the case of World War One. And today it is not only the threats of economic devastation and war we need to worry about, but also the potentially existential threat posed by climate change.

The choice we are facing today is no less stark than that which Luxemburg saw confronting humanity at the height of World War One. Will we allow the continuation of the system that is propelling humanity into one catastrophe after another? Or will we unite

country but a version of interventionist state capitalism (in contrast to neoliberal and militarized state capitalism in the USA), having intricate social control and digital surveillance systems. The potential rise of China's version of state capitalism to the position of the new hegemonic power, will not, according to the critics, improve substantially the perspectives of socialist transformation of the present world system.

There is, however, a recent study by the Harvard University, which, after thirteen years of exploration, detected the growing support among the Chinese population to the government in Beijing from $86 \%$ in 2003 to $93 \%$ in 2016. The researchers conclude that the Communist Party of China is in power because it has improved the existence of Chinese people. It therefore continues to enjoy the people's active consent to the rule of the Communist Party, which has pulled 800 million inhabitants out of poverty, while the middle class has risen to include over 400 million inhabitants (Korkodelović, 5. jul 2021: 23; Vratuša, 2018b).

15 A logical conclusion of policies of the reformist and opportunistic wing within the GSDP is the Godesberg Program (1959), in which the German SPD dropped its commitment to Marxism and turned to appeal to middle-class voters, becoming a big tent party of the centre-left. This change of course from the "party of the working class to a party of the people" - the SPD explicitly ceases to stand for socialism of the Marxist variety like Rosa did. Private property and free market principles were acknowledged, and the role of the state was limited to general tasks involving planning and guidance. The program was rounded out by the affirmation of the importance of national defense and socio-political demands, such as co-determination in the workplace, equality for women, and improved educational opportunities. 
against this system and its defenders (even those supposedly "on our side"), and set a course for a revolution? Do we want merely to win a somewhat friendlier version of capitalism, or will we fight for a society and economy democratically and collectively controlled by workers, in which the vast capacities and resources of humanity are no longer sacrificed on the altar of the market, but can be turned to restoring our damaged relationship with nature, and to providing the things we need to live a decent life?

If we want to overcome the barbarism of capitalism, then the need for the kind of clear, intransigent revolutionary politics exemplified by Rosa Luxemburg's life and thought is more urgent today than ever.

The arguments of today's reformists bear a striking resemblance to Bernstein's. As such, Rosa Luxemburg's critique retains its relevance to the debates taking place in the left wing at present.

The turn to the center right political parties in power has resulted in pessimism within the global justice movement, which leads to withdrawal from activism and bitter inner fighting between those who insist either on the policy of seeking state power or cultural transformation instead of simultaneously insisting on both (Wallerstein, February 15, 2019). An important lesson we can draw from Rosa's $R o R$ is to insist on the socialist-oriented political content of economic and socio-cultural reforms. 
Вера А. Вратуша Жуњић ${ }^{1}$

Универзитет у Београду, Филозофски факултет,

Одељење за социологију

Београд (Србија)

\title{
СТО ПЕДЕСЕТ ГОДИНА ПОСЛЕ РОЪЕЊА РОЗЕ ЛУКСЕМБУРГ: АКТУЕЛНОСТ ЊЕНЕ ДРУШТВЕНЕ РЕФОРМЕ ИЛИ РЕВОЛУЦИЈЕ
}

\author{
(Превод In Extenso)
}

Сажетак: Рад истражује актуелност Реформе и револуције Розе Луксембург 150 година након њеног рођења.

Основни коришћени метод је анализа садржаја овог значајног политичког памфлета, смештена у контекст времена/простора када и где је написан, с једне стране, и данас, с друге.

Основни налаз јесте да је Розино дело остало релевантно до наших дана с обзиром на то да капиталистички начин производње и даље одликују унутрашње противречности које производе варварске последице израбљивања и империјалистичких ратова. Ове последице капиталистичког система осигуравају трајну актуелност дилеме социјализам или варварство с којом се Роза Луксембург суочавала током целокупног својег живота.

Кључне речи: реформа, револуција, капитализам, утопијски социјализам, научни социјализам, варварство

\section{Увод}

Другу и почетак треће деценије XXI века одликује нови период релативне стабилизације капиталистичког начина производње од када се смирила финансијска криза 2007/2008 године, нарочито у центру светске капиталистичке привреде (Wallerstein, I, 1974). До сада, чак ни трајућа светска рецесија коју су донеле привредне последице светске пандемије COVID-19 (уп. тематско издање Социолошкої йреїлеgа Друштво \& COVID-19, 2020), није много пореметила ову стабилизацију. Текућа привидна стабилизација капитализма је довела на власт углавном централно десно оријентисане идеолошке представнике финансијске буржоазије, за разлику од глобалних политичких борби које су наизглед биле наклоњене светској левици у првој деценији XXI века.

1 vera.veritas@gmail.com 
Чланови покрета који су упркос поменутим друштвеним околностима ипак остали трајно и стратешки оријентисани на структурални преображај израбљивачких капиталистичких друштвених односа, који се нису предали песимизнму и неактивности, имају тенденцију да трагају за инспирацијом и лекцијама за антикапиталистичку револуционарну теорију и праксу у животу и делу доследних марксистичких револуционара каква је била Роза Луксембург (1871-1919). Савремено преиспитивање Розиног дела Реформа или револуција (1900, у даљем тексту РиP) представља добру полазну тачку за извлачење поменутих поука у околностима релативне стабилизације капитализма. Роза је, наиме, написала првих пет поглавља РиР у сличним околностима на крају XIX века, тј. привидног одсуства отворене класне борбе између радних маса и финансијске олигархије у Немачкој и шире. РиР представља полемичку реакцију и марксистичку критику теорије коју је Едвард Бернштајн (1850-1932) представио у својој књизи Преgуслови социјализма и заgаци социјалgемокрайије (Die Voraussetzungen des Sozialismus und die Aufgaben der Sozialdemokratie, преведене на енглески као Еволуциони социјализам (1899/интернет верзија б.г.)).

Роза је рођена у породици Јевреја у Пољској под руском окупацијом. Непогодности као што су род, инвалидност и јеврејско порекло нису је спречиле да стекне докторат Универзитета у Цириху, да постане поштована академска теоретичарка, новинарка, анти-ратна активисткиња и бескомпромисна социјалистичка револуционарка која неуморно преиспитује оне на власти (Evans, 2015).

\section{Реформа vs. револуција и ситна буржоазија vs. пролетаријат}

Упркос наслову својег рада, Роза Луксембург инсистира да она не супротставља дневне синдикалне економске борбе и агитацију за друштвене реформе и демократизацију постојећих политичких институција, које побољшавају животне услове радника, с једне стране, и крајњи циљ - освајање политичке власти и укидање најамног рада, с друге. Роза се слаже да су синдикална и парламентарна пракса значајне за подизање социјалистичке свести пролетаријата и за његово организовање као класе.

Роза разјашњава да она критикује Бернштајнов предлог радницима да се одрекну друштвеног преобликовања и да учине од друштвених реформи крајњи циљ класне борбе. Бернштајн лоцира остварење социјализма у могућност претварања сиромашних у богате, у смањивање класних антагонизама и капиталистичких криза. С обзиром на то да не може да постоји социјалистички покрет без социјалистичког циља, Бернштајн завршава одричући се покрета.

Тиме Бернштајн, према Розином мишљењу, своди целокупан раднички покрет против капиталистичког поретка на једноставни напор да се он поправи. У таквом предлогу Роза открива Бернштајнов покушај да обезбеди превласт ситно-буржоаским елементима у оквиру покрета радних маса који спутавају његов пролетерски карактер. Она сматра да је од највећег значаја да се велика маса радника оштроумно заинтересује за теоријске дебате о социјализму и на тај начин преузме „поуздано оружје научног социјализма у властите руке, тако да све ситно-буржоаске опортунистичке струје пропадну" (https://www.marxists.org/archive/luxemburg/1900/reformrevolution/intro.htm). 


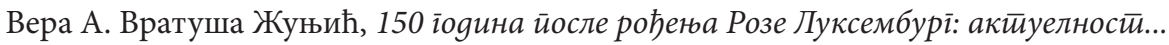

Роза инсистира да разлика између ње и ревизиониста у СДПН није у томе $и \bar{u} a$ него у томе како је синдикална и парламентарна активност политички оријентисана (https://www.marxists.org/archive/luxemburg/1900/reform-revolution/ch05.htm).

У наредним поглављима Роза разрађује узајамно повезане основне теме наговештене у Уводу. У анализи њиховог садржаја стога понекада није могуће избећи извесну репетитивност која одликује и Розин текст, ма колико се аутор овог рада трудио да подели различите, међусобно испреплетене теме, у засебне одељке. Важан извор овог понављања је педагошке природе, с обзиром на то да се Роза обраћа радницима као читалачкој публици, па понављање има функцију утувљивања основних идеја о социјализму и борби за његово остваривање у свест читалаца.

\section{Научни социјализам и дијалектички метод и утопијски социјализам и опортунистички метод}

Основни елеменат научног социјализма, према Рози, је, пре свега, растућа анархија капиталистичке привреде која неминовно води ка њеној пропасти. Други елеменат научног социјализма је прогресивно подруштвљавање процеса поизводње које ствара заметке будућег друштвеног поретка. Трећи основни елеменат је повећана организација и освешћивање пролетерске класе, што представља активни фактор друштвене револуције.

Бернштајн игнорише или негира сва три поменута елемента научног социјализма. Роза започиње своју критику Еволуционої социјализма анализом „опортунистичког метода” који користи Бернштајн док развија своју утопистичку теорију. Основна одлика Бернштајновог опортунистичког метода је његово негирање саме могућности преображаја у социјализам услед општих унутрашњих противречности између производње и размене на капиталистичкој основи, водећи у крањем резултату слому капитализма. Пошто се капиталистички развој, према Бернштајну, не креће у смеру властитог пропадања, социјализам престаје да буде објективно нужан резултат материјалног развоја друштва. Бернштајн на овај начин уклања програм социјалистичког покрета са његове материјалне основе и покушава да га постави на идеалистичку, утопијску основу (https://www.marxists.org/archive/luxemburg/1900/ reform-revolution/ch01.htm) $)^{2}$.

2 У поглављу Економски развој и социјализам (https://www.marxists.org/archive/luxemburg/1900/ reform-revolution/ch06.htm) Роза подвлачи још једном да је откриће утемељења ослонца за остваривање социјализма у економским условима капиталистичког друштва променило социјализам из утопијског идеала у историјску нужност. Бернштајн, напротив, негира постојање економских услова социјализма у противречностима капитализма. За Бернштајна социјализам је постао једино преживљавање утопизма. Он је бивши социјалиста који се одрекао својег циља и одлучио да у буржоаском друштву пронађе једини и непроменљив циљ људског развоја. Бернштајн негира анархију у капиталистичкој привреди и велику општу кризу услед противречности између производње и размене. За Бернштајна, Марксов друштвени рад је чиста апстракција. Он не признаје да апстрактни људски рад, закон вредности, опадајућа стопа профита коју је открио Маркс као резултат противречности између производње и размене и пораста продуктивности рада, имају стварно друштвено постојање 
Опортунизам одликује непријатељство према „теорији”. Под теоријом Роза подразумева принципе научног социјализма који намећу ограничења циљевима, средствима и методима примењеним у практичној делатности радничког покрета. Бернштајн је стога покушао да елаборира нову теорију, легитимизујући опортунистичке струје деловања, уједињујући све опортунистичке елементе на Штутгартском конгресу Друге интернационале 1907. године, гурајући раднички покрет на буржоаске путеве.

Роза инсистира да је опортунистичка теорија која се састоји у утемељењу социјализма на моралним представама о правди, на борби против начина расподеле, уместо да је утемељује у борби против начина производње, на замисли класног антагонизма као антагонизма између сиромашних и богатих, на напору да се накалеми „кооперативни принцип” на капиталистичку привреду, већ постојала пре Бернштајна. Она додаје да након развоја класне борбе и њеног одраза у њеним друштвеним околностима дошло до напуштања опортунистичких теорија и до развијања принципа научног социјализма. Роза наглашава да социјализма не може бити - барем не у Немачкој - изван марксистичког (научног) социјализма. Враћање пред-марксистичким социјалистичким теоријама значи враћање у слабашне изношене папуче буржоазије (https://www.marxists.org/archive/luxemburg/1900/reform-revolution/ch10.htm).

Одбацујући Марксову економску доктрину и дијалектички метод Бернштајн је заменио научну основу еманципације радничке класе апологетиком буржоазије, лишавајући социјалистички покрет његовог класног карактера. Нападајући дијалектички метод Бернштајн покушава да сломи интелектуално оружје помоћу којега је пролетаријату омогућено да проникне пролазну природу капиталистичког јарма, остварујући револуцију у домену мисли (https://www.marxists.org/archive/luxemburg/1900/ reform-revolution/ch06.htm).

По Розином мишљењу, основна противречност капитализма, као што смо видели, постоји између неограничених могућности раста капиталистичке производње, с једне стране, и недовољне куповно способне потражње за произведеном робом на тржишту, или криза хиперпродукције, с друге (https://w ww.marxists.org/archive/luxemburg/1900/ reform-revolution/ch01.htm). Због ове противречности капитал води империјалистичке ратове да би припојио до тада некапиталистичка друштва светском капиталистичком тржишту. Према Рози, на крају ће доћи до слома капитализма када империјалистичка буржоазија преузме последња још увек некапиталистичка тржишта³

у облику пролазног карактера капиталистичке привреде. Управо зато што је Маркс заузео становиште социјализма као полазну тачку за своју анализу буржоаског друштва, он је, према Рози, био у прилици да пружи научну основу социјалистичком покрету кроз дуализам класног антагонизма буржоазије и пролетаријата.

3 Критичари Розине књиге у којој она детаљно разматра основну унутрашњу противречност капитализма која на крају води његовом слому, Акумулација кайийала (Luxemburg, 1913/online version s.a.), критикују Розине основне аргументе изражене у њој због пренаглашавања противречности капиталистичке кризе хиперпродукције у сфери размене и занемаривања кризе хиперакумулације капитала у производном процесу. Критичари тврде да основни мотив империјалистичке експанзије је потреба не само за остварањем нових тржишта у још увек не-капиталистичкој периферији, неопходних за реализацију произведених роба, него и за искоришћавање јефтинијих сировина и јефтиније радне снаге (Bottomore, Harris, Kiernan, Miliband.1983: 293-4). Ови критичари потцењују Розин 
Вера А. Вратуша Жуњић, 150 іолина йосле рођења Розе Луксембурї: акйиелносй...

\section{Критика Бернштајнових аргумената о способности капитализма да се „прилагоди”}

Капиталистичко друштво, према Бернштајну, нема унутрашњу тежњу ка слому него, напротив, оно има способност „прилагођавања” тако да општи слом капиталистичког система производње постаје све мање вероватан. Роза испитује ове наводне механизме „адаптације” капитализма потребама друштва један по један (кредитни систем ${ }^{4}$; организације послодаваца, картели и трустови ${ }^{5}$; стално опстајање „чврсте фаланге” малих и средњих предузећа ${ }^{6}$; појачана синдикална и парламентарна актив-

допринос разумевању да империјалистички ратови представљају глобализовано ширење капиталистичког израбљивања, а не само још једну владину политику између осталих. У својем тексту „Роза Луксембург и актуелност револуције” Пол Лебланк (Nov. 17, 2019 ) стога истиче да чак и онда када Роза делимично или углавном није у праву, њене текстове вреди разумевати, активно разматрати и проверавати, док год одлучни социјалисти покушавају да разумеју и промене свет.

4 Кредитни систем представља, према Рози, средство привременог превазилажења граница приватног власништва, да би се пропширила капиталистичка производња путем комбиновања великог броја индивидуалних капитала у облику индустријског или комерцијалног кредита. Далеко од тога да представља облик прилагођавања капитализма, кредит на први знак кризе напушта размену и своди на минимум потрошачку способност тржишта. Он је тако моћно оруђе за обликовање криза услед унутрашње противречности између готово неограничене способности ширења производње, на једној страни, и ограничене потрошачке способности тржишта, с друге. Кредит ставља у мали број руку огромне производне снаге разбаштињујући велики број малих капиталиста и водећи до спекулације власништвом милиона малих власника деоница (https://www.marxists.org/archive/luxemburg/1900/reformrevolution/ch02.htm). Кредит стога представља неопходан зупчаник у механизму противречне капиталистичке привреде као што су то новац или тржиште. Кредит је истовремено оруђе уништења капиталистичке привреде, пошто погоршава унутрашње противречности капитализма (https://www.marxists.org/archive/luxemburg/1900/reform-revolution/ch05.htm).

5 Организације послодаваца, картели и трустови, према Рози, такође нису у стању да зауставе анархију капиталистичке производње кроз регулацију, као што сугерише Бернштајн, пошто они нису и не могу да буду доминантан облик целокупне капиталистичке производње. Они представљају друштвени карактер капиталистичке производње и теже да повећају стопу профита у једној грани индустрије на рачун друге, али картели не могу да буду уопштени. Одржавајући неактивним један део акумулираног капитала, они заоштравају кризу и такмичење за потрошаче на страним тржиштима, која ће пре или касније да постану исцрпљена. Картели такође погоршавају израбљивање рада и увећавају антагонизам између капитала и рада до екстрема (https://www.marxists.org/archive/luxemburg/1900/reform-revolution/ ch04.htm).

6 Трајно постојање „чврсте фаланге” малих и средњих предузећа представља, према Рози, пионире техничке промене који се налазе под утицајем две супротстављене тенденције: периодичног обезвређивања постојећег капитала, с једне стране, и сталног раста размера производње и повећања минималне количине капитала потребне за функционисање предузећа у старим гранама производње, с друге (https://www.marxists.org/archive/luxemburg/1900/ reform-revolution/ch02.htm). Бернштајн заборавља на неопходност новог пласирања малог и средњег капитала током цикличних криза. Услед овога константно се поново појављује ситан капитал који Бернштајну изгледа да представља знак престанка капиталистичког 
ност $^{7}$; радно законодавство социјалне заштите ${ }^{8}$; кооперативни принцип $\left.{ }^{9}\right)$, и показује да они у ствари продубљују противречности капитализма.

Роза закључује да не може постојати постепена експропријација средстава за производњу на темељу прогресивног ширења контроле над условима производње кроз синдикалну борбу и политичке реформе, које би, према Бернштајну, постепено

развоја, упркос томе што је реч о симптому нормалног капиталистичког развоја кроз цикличне кризе (https://www.marxists.org/archive/luxemburg/1900/reform-revolution/ch05.htm). Бернштајн пропушта да примети да се просечни оснивачки капитал деоничарских друштава смањио, указујући на подруштвљавање не само крупне него и средње и ситне производње. Деоничарство представља одвајање производње од капиталистичког власништва на капиталистичкој основи.

7 Синдикати, према Рози, не могу да пруже радницима одређујући утицај над производњом, ни над њеним димензијама нити над техничким напретком. Закон надница није уздрман него примењен кроз активност синдиката. Синдикати нису ништа више него организована одбрана радне снаге против напада профита. Удео друштвеног богатства који одлази радничкој класи је смањен фаталношћу природног процеса пораста производности рада и ситуацијом на тржишту радне снаге услед пролетаризације средњих слојева друштва (https://www.marxists.org/archive/luxemburg/1900/reform-revolution/ch07.htm).

Функција синдиката се састоји у обезбеђивању радника средствима остваривања капиталистичког закона надница, продаје њихове радне снаге по текућим тржишним ценама, зависно од конјунктуре потражње и понуде рада и од продуктивности рада. Синдикати, међутим, нису у стању да потисну закон надница, израбљивање и утицај процеса саме производње. С обзиром на то да је смањивање надница једно од главних средстава за успоравање тенденције профита да опада, синдикална делатност је сведена на једноставну одбрану већ остварених добити. Роза закључује да стога политичка страна класне борбе мора да буде развијена.

Бернштајн, према Рози, усмерава целокупну делатност синдиката ка даљем побољшавању економског и политичког положаја пролетаријата кроз преговарање о надницама, кооперацију и парламентарне изборе.

Роза резимира да због Бернштајновог третирања синдикалне и парламентарне активности као оруђа непосредног подруштвљавања капиталистичке привреде ова активност. у ствари. губи ефикасност, сведена на циљ сам по себи. Она не води крајњем циљу социјализма него се креће управо у супротном смеру. Ова активност тако престаје да буде оруђе припремања радничке класе за освајање власти, Социјалдемократе треба, напротив, да охрабрују раднике да схвате немогућност постизања темељне друштвене промене само кроз синдикалну и парламентарну делатност и да је освајање власти неизбежно.

8 Радно законодавство социјалне заштите, за разлику од Бернштајна, Роза не види као део „друштвене контроле” и социјализма. Држава, наиме, није „друштво” које представља „наступајућу радничку класу”, него представља класну организацију која репрезентује капитал (https://www.marxists.org/archive/luxemburg/1900/reform-revolution/ch03.htm).

9 Бернштајн преображава социјализам, према Рози, од дефинитивне историјске фазе друштвеног развоја у апстрактни „кооперативни принцип”. Економска демократија и кооперативе (https://www.marxists.org/archive/luxemburg/1900/reform-revolution/ch07.htm) наводно ће постепено да потисну индустријски профит и трговачки профит у сфери произуводње, сугеришући да не постоје антагонистичке класе у капиталистичком друштву, признајући буржоазију као заговорника општих интереса човечанства, проповедајући радничкој класи суштину моралности буржоазије, то јест, помирење са постојећим 
Вера А. Вратуша Жуњић, 150 іолина йосле рођења Розе Луксембурї: акйуелносй...

свеле права власника на улогу једноставних администратора. Крупни капиталисти, према Рози, напротив, постали су крупни акционари одвојени од сваког личног односа са управљањем производњом (https://www.marxists.org/archive/luxemburg/1900/ reform-revolution/ch03.htm).

\section{Капиталистичка држава, парламентаризам и освајање демократске политичке власти}

Роза разрађује своје погледе на државу као класну организацију капитала, подвлачећи да капиталистички развој чини државну интервенцију и контролу у друштву све више нужнима. Међутим, држава у капитализму остаје организација владајуће класе која примењује политику царина, милитаризма и колонијалног империјализма. Стога парламентаризам изражава друштво у којем преовлађују капиталистички интереси. Отуда је илузија реформиста да ће противречност између класне државе и друштва бити елиминисана кроз увећану државну контролу и напредак демократије. Роза је уверена да једино освајање политичке власти од стране пролетаријата може да оствари демократију нужну и незаобилазну радничкој класи за аутономно управљање у њеном задатку преображавања буржоаског друштва (https://www.marxists. org/archive/luxemburg/1900/reform-revolution/ch04.htm).

Бернштајн представља социјализам не као последицу економске принуде него као резултат осећања правде и воље као и пораста демократије. Роза показује да се не може конструисати апсолутни општи однос између капиталистичког развоја и демократије. Демократске институције су потпуно исцрпиле своју функцију помоћи у развоју буржоаског друштва. Либерализам је чак почео да представља препреку капитализму због светске политике и погоршавања такмичења на светском тржишту и јачања радничког покрета. Судбина демократије је повезана са судбином радничког покрета. Остваривање демократије захтева освајање политичке власти од стране радних маса (https://www.marxists.org/archive/luxemburg/1900/reformrevolution/ch08.htm).

У свом значајном политичком памфлету Руска револуција (1918/1999) Роза истовремено примећује ограничења представничке демократије, али такође захтева да револуција унапређује представничку демократију. У четвртом поглављу она критикује Лењина (1870-1924) и Троцког (1879-1940) зато што су укинули изабрану Конститутивну скупштину непосредно након Октобарске револуције ${ }^{10}$. Роза за-

друштвеним поретком. Роза подсећа читаоце да у капиталистичкој привреди немилосрдно израбљивање постаје услов за опстанак сваког предузећа. Радници који формирају кооперативе су принуђени да преузимају према самима себи улогу израбљујућег капиталисте тако да кооперативе било постају чиста капиталистичка предузећа која се такмиче на тржишту или завршавају распадајући се уколико немају залеђе потрошачких организација. Оне су искључене из најважнијих грана капиталистичке производње. Успостављање произвођачких кооператива широких размера би претпостављало потискивање светског тржишта. 
кључује славним слоганом да је слобода увек слобода за оне који мисле другојачије. Њена критика репрезентативне демократије спречава нас да протумачимо овај слоган као захтев за недискриминаторном општом толеранцијом.

Са ревизионистичког становишта, показује Роза, освајање власти је истовремено немогуће и бескорисно. Социјализам наводно може једино да се уведе као резултат деловања синдиката и парламента. Ово деловање има социјалистички карактер према ревизионистима зато што оно наводно врши прогресивно подруштвљавајући утицај на капиталистичку привреду.

Роза заправо аргументује да је овај подруштвљавајући утицај чисто илузоран с обзиром на то да се синдикална и парламентарна активност у пракси спроводе искључиво због њихових непосредних резултата моменталног побољшавања садашње ситуације радника. Оне у Бернштајновој ревизионистичкој теорији и пракси губе сваку повезаност са политичким радом за социјализам пошто искључују припремање пролетаријата, субјективног фактора социјалистичког преображаја, за задатак остваривања социјализма (https://www.marxists.org/archive/luxemburg/1900/reformrevolution/ch05.htm) .

\section{Маргиналистичка, вулгарна, механичка буржоаска економска теорија}

Бернштајнова маргиналистичка и механичка економска теорија представља други моменат због којег Роза критикује Бернштајнову теорију и методу. Према овој теорији, капиталиста је виђен као изоловани предузетник који одражава у својем мозгу економске чињеница око себе само како се оне појављују када су преломљене кроз призму закона конкуренције. Изоловани капиталиста види сваки органски део целокупне капиталистичке привреде (кредит, новац, картеле, мала и средња предузећа...) као међусобно независне ентитете. Он их види онако како они делују на њега, појединачног капиталисту нарочито током криза. За изолованог капиталисту кризе су стварно једноставни поремећаји док му престанак криза омогућује дуже постојање. Што се тиче појединачног капиталисте, кредит му, на пример, представља једино средство да „прилагоди” своје недовољне производне снаге потребама тржишта. Стога му се чини да картел чији он постаје члан заиста потискује индустријску анархију (https://www.marxists.org/archive/luxemburg/1900/reform-revolution/ch05.htm).

Маргинализам завршава у утопији и програму реакције. Роза дефинише теорију ревизионизма као теорију стајања у месту у оквиру социјалистичког покрета, изграђеној на теорији капиталистичког застоја (https://www.marxists.org/archive/ luxemburg/1900/reform-revolution/ch05.htm).

Троцки и Лењин, елиминација демократије као такве, је гори од болести коју би требало да лечи; то је зато што зауставља сам животни извор из којега једино могу да долазе корекције свих унутрашњих недостатака друштвених институција. Тај извор је активан, неспутан, енергичан политички живот најширих народних маса" (https://www.marxists.org/archive/ luxemburg/1918/russian-revolution/ch04.htm). 
Вера А. Вратуша Жуњић, 150 іолина йосле рођења Розе Луксембурї: акйуелносй...

Као контраст Бернштајновој маргиналистичкој теорији, према којој „капиталиста” није једна економска јединица, чинилац производње, него пореска јединица, одређена количина новца, Роза инсистира да индустријски капиталиста представља колективну личност састављену од стотина и чак хиљада појединаца.

Роза резимира да ревизионизам није ништа друго него теоријско уопштавање направљено из угла изолованог капиталисте, то значи са становишта вулгарне буржоаске економике. Све грешке буржоаске економике почивају управо на замисли која замењује феномене конкуренције, виђене из угла изолованог капиталисте, за феномене целокупне капиталистичке привреде. Ова вулгарна економика покушава да пронађе противлек за болести капитализма у феноменима капитализма. Вулгарни економиста верује да је могуће да се регулише капиталистичка привреда и да се ублаже противречности капитализма.

\section{Ублажавање класних антагонизама, криза и ситнобуржоаско одрицање од социјалистичког циља}

У складу са својом тврдњом о прилагодљивости капиталистичког начина производње и размене, Бернштајн интерпретира капиталистичке кризе као једноставне поремећаје привредног механизма. Он, наиме, верује да би са престанком криза капиталистички механизам могао добро да функционише. Роза, напротив, наглашава да кризе нису једноставни „поремећаји” у уобичајеном значењу те речи: кризе су „поремећаји” без којих капиталистичка привреда не би могла уопште да се развија. Кризе, у ствари, представљају једини могући природан метод у капитализму за периодично решавање сукоба који постоји између неограниченог ширења производње и уских граница светског тржишта. Кризе су стога органска манифестација неодвојива од капиталистичке привреде. Због периодичног обезвређивања капитала, кризе доносе пад у ценама средстава за производњу, парализу једног дела активног капитала. Временом долази до пораста профита који тако ствара могућност обновљеног напредовања рапламсале ватре капиталистичког развоја.

У поглављима $P$ РP која је редиговала након искустава револуције у Русији 1905 године и после ње Роза такође истиче да тек што је Бернштајн елаборирао своје аргументе о „адаптацији” капитализма кроз кредитни систем, картеле и трустове, дубока општа трговачка криза је избила 1907/8 године управо у земљама у којима су били најразвијенији кредит и трустови (https://www.marxists.org/archive/luxemburg/1900/ reform-revolution/ch02.htm).

Роза закључује да анархична капиталистичка производња не може да се „прилагоди" размени и на тај начин постане трајан систем производње пошто светско тржиште не може да се шири без граница (https://www.marxists.org/archive/luxemburg/1900/ reform-revolution/ch05.htm). Пре или касније светско тржиште ће бити проширено до своје границе и биће исцрпљено кроз такмичење капиталистичких земаља (https:// www.marxists.org/archive/luxemburg/1900/reform-revolution/ch02.htm) (уп. ФН ii).

Роза тврди да ће социјализам бити последица 1) растућих унутрашњих противречности капиталистичке привреде које ће се заоштравати уместо да нестају и 2) 
разумевања од стране радничке класе неизбежности подјармљивања ових противречности кроз друштвени преображај. Пошто ревизионизам негира прву противречност и другу одбацује, он раднички покрет редукује на једноставан реформистички покрет који је напустио класно становиште радничке класе и постаје становиште капиталистичких апологета.

\section{Утопизам и реакционарност}

Роза разоткрива Бернштајнову теорију као истовремено утопијску и реакционарну. Роза поново наглашава, пре свега, да дефектан капиталистички развој погођен кризама не може да води до социјалистичког преображаја зато што се ни кредитни систем нити картели и преживљавање средњих класа не могу сматрати „средствима адаптације” капиталистичке привреде упркос привременим прекидима криза, које увек изнова избијају у још оштријем облику.

Бернштајн се, према Рози, одриче борбе против капиталистичког начина проиводње и покушава да усмери социјалистички покрет на борбу ка праведнијој „расподели". С обзиром на то да је начин производње узрок начина расподеле, социјална демократија би требало да се бори за угушење капиталистичке производње саме.

Бернштајна сагледава законодавни ток историјског развоја као деловање методичне „интелигенције” док је револуционарни ток историјског развоја за њега деловање спонтаног „осећања”. У историји буржоаског друштва. према Рози, законодавна реформа је служила да прогресивно ојача класу у успону док ова не постане довољно снажна да освоји политичку власт, да угуши постојећи правни систем и да сама конструише нови.

Роза резимира $Р$ Р познатим слоганом: „Законодавна реформа и револуција нису различити методи историјског развоја који могу да се бирају према нахођењу са полице историје, као што се бирају топле или хладне кобасице. Законодавна реформа и револуција допуњују једна другу, али су у исто време узајамно искључиве, као што су северни и јужни пол, буржоазија и пролетаријат”. Људи који се изјашња-

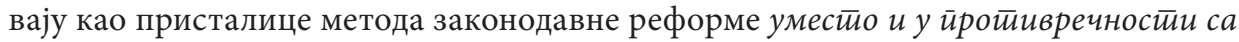
освајањем политичке моћи и социјалном револуцијом, доиста не бирају мирнији,

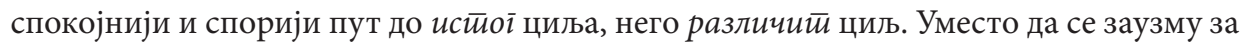
успостављање новог друштва они заузимају становиште површних модификација старог друштва, потискивања злоупотреба капитализма, уместо уништења самог капитализма" (https://www.marxists.org/archive/luxemburg/1900/reform-revolution/ ch08.htm).

Роза наглашава да законодавна реформа капитализма није могућа зато што класна доминација у оквиру ње не почива на „стеченим правима” него на стварним економским односима доминације капитала над радом схваћеним као роба која поседује одлику да поизводи вишак вредности већи од вредности коју конзумира. Стога најамно ропство не може да буде потиснуто „законодавним путем”.

Бернштајн упозорава пролетаријат на опасност од прераног стицања политичке власти. У позадини овог става Роза открива уверење да је социјалистички програм 


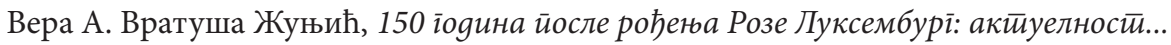

неостварив и да изражава опште супротстављање аспирацијама пролетаријата да сам поседује државну власт. ${ }^{11}$

Роза тврди да освајање власти претпоставља одређени степен зрелости економских и политичких односа и крупну свесну народску класу као производ растакања буржоаског друштва. Социјалистички преображај претпоставља дугу и упорну борбу током које ће пролетаријат вероватно бити одбијен више него једанпут. Ови „преурањени” напади пролетаријата представљају врло значајан чинилац који ствара политичке услове за трајно очување политичке власти.

\section{Опортунизам у теорији и пракси}

Роза показује да се опортунизам појавио као јасно дефинисана струја у немачком радничком покрету са укидањем анти-социјалистичких закона 1887. године (које је власт увела 1881. у страху од наглог пораста бројности и организованости радничког покрета) (https://www.marxists.org/archive/luxemburg/1900/reform-revolution/ ch10.htm).

Социјалдемократски покрет, наглашава Роза, мора да пипа по мраку на својем путу развоја између следеће две стене: напуштања масовног карактера партије или напуштања њеног крајњег циља, западајући у буржоаски реформизам или у сектаријанизам, анархизам или опортунизам. С обзиром на то да је социјалдемократски покрет масован и зато што опасности његовог угрожавања не потичу из људског мозга него из друштвених услова, марксистичка доктрина не може да нас осигура, унапред и једном заувек, против анархистичких и опортунистичких тенденција.

Роза подвлачи да изненађујућа ствар није појава опортунистичке струје у последњој деценији XIX века него, пре свега, њена слабост зато што у њој нема ни сенке оригиналне мисли: „Нема ниједне идеје која није побијена, сведена на прашину од стране марксизма пре неколико деценија! Једино дијалектика и материјалистичка замисао историје... могли су да учине да се Бернштајн појави као несвесни предодређени инструмент путем којега растућа радничка класа изражава своју тренутну слабост, али који, након ближег испитивања, одбацује у страну с презиром и поносом (https:// www.marxists.org/archive/luxemburg/1900/reform-revolution/ch10.htm).

11 У Розиној књизи РиР може се открити такозвана „државно-центрична” политичка култура када она инсистира, попут Лењина и Троцког, а за разлику од Бернштајна, на нужности да радници освоје државну власт. Неки домородачки народи, као запатисти у Мексику, реагују ненасиљем односно ненасилном и ненаоружаном самоодбраном, изграђујући просторе здравства и школства, инфраструктуре, домородачке гарде без оружја. Ово је утемељено присуство заједнице у којој се људи ослањају једни на друге и једино имају своја тела да се одбране у својим аутономним зонама са сајмовима натуралне размене. Они бирају да буду ненасилни зато што не желе да копирају насиље државе (Zibechi, R. 2021, May 21). Проблем је садржан у чињеници да владе датих земаља често не дозвољавају домородачком народу да мирно изгради своју властиту аутономну заједничку друштвену инфраструктуру, посежући у заједницу домородачког народа са својим екстрактивистичким и урбанистичким пројектима који раздвлашћују локалне заједнице од њихове земље. 


\section{Закључак}

Својим памфлетом РиР Роза је успела једино да у првој деценији ХХ века Карл Кауцки (1854-1938), најауторитативнија марксистичка теоријска личност Друге интернационале, бар на речима остане привржен социјалистичком циљу током конференција СДП и Друге интернационале. Међутим, када су сви делегати у парламенту, укључујући чланове СПД, 4. августа 1914 гласали за ратне кредите, они су издали радничку класу и крајњи циљ прелаза ка социјализму, омогућавајући и чак подстичући улазак Немачке у варварски империјалистички светски рат ${ }^{12}$.

Пораз у Великом рату 1918. године подстакао је у Немачкој револуционарно превирање међу радницима. Роза Луксембург и Карл Либкнехт су поздравили револуционарну тактику ванпарламентарне масовне акције, полуспонтаних масовних штрајкова који избијају у револуционарним ситуацијама екстремног тлачења и/или исцрпљујућих ратних напора (Rosa Luxemburg, 1905), док први успеси не ојачају и подигну самопоуздање радника. Историјски догађаји су превазишли Розине сугестије из времена стабилизације капитализма када је препоручивала да би синдикалне борбе требало да имају револуционарну компоненту (попут захтева за поседовањем

12 Роза Луксембург у првом поглављу Junius Pamphlet (Luxemburg: 1915b/1996) приписује Фридриху Енгелсу (1820-1895; суоснивач „научног социјализма” са Карлом Марксом (1818-1883); Vratuša, 2020b), славну дилему „социјализам или варварство”. Роза није прецизно цитирала извор пошто је овај памфлет писала у затвору: „Буржоаско друштво стоји на раскршћу, било прелаз у социјализам или назадовање у варварство." Роза наставља да разрађује значење ове дилеме у тада актуелном историјском контексту: „Шта 'назадовање у варварство’ значи за нашу узвишену европску цивилизацију?... Овај светски рат је назадовање у варварство. У почетку, ово се дешава спорадично за време трајања савременог рата, али онда када започне период неограничених ратова он напредује ка својим неизбежним последицама. Данас се суочавамо са избором као што је то Фридрих Енгелс предвидео једну генерацију раније: било тријумф империјализма и колапс цивилизације као у старом Риму, депопулација, пустош, дегенерација - велико гробље. Или победа социјализма, што значи свесну активну борбу међународног пролетаријата против империјализма и његових метода ратовања. То је дилема светске историје, једно или/или; тасови на ваги трепере пред одлуком класно-свесног пролетаријата. Будућност цивилизације и човечанства зависи од тога да ли хоће или неће пролетаријат да мушки убаци свој револуционарни мач на вагу. У овом рату империјализам је победио. Његов крвави мач геноцида је брутално померио тасове ваге ка понору беде. Једина надокнада за сву беду и сву срамоту било би уколико бисмо научили из рата како пролетаријат може да уграби у своје руке владање властитом судбином и тако избегне улогу лакеја владајућих класа" (Luxemburg, 1915b/1996, www. marxists.org/archive/luxemburg/1915/junius/ch01.htm).

Године 1918. Роза заоштрава свој закључак из РиР о Другој интернационали, тврдећи да је она већ била изнутра трулеће тело и да успех реформистичког градуализма да преобрази капитализам на еволуциони начин није могућ.

Суочени са буржоаским опортунизмом и издајом немачке СДП, Роза Луксембург, Карл Либкнехт (1871-1919), Клара Цеткин (1875-1933) и други, заједно су основали током Првог светског рата анти-ратни и анти капиталистички Спартаков савез који су они преобразили у Комунистичку партију Немачке и придружили се Трећој комунистичкој интернационали 1919. године. 
Вера А. Вратуша Жуњић, 150 іолина йосле рођења Розе Луксембурї: акйиелносй...

предузећа и одлучивање радника, на пример, шта, где, како и колико да се производи и расподељује) с обзиром на то да капиталистички систем може у било које време да укине сваку парцијалну реформу, као што се то десило са Рузвелтовом „Новом погодбом” или „Трећим путем” Тонија Блера.

Оснивање Комунистичке партије Немачке 1918. године, међутим, догодило се сувише касно да би се придобила већина радничке класе за револуционарну марксистичку оријентацију током револуционарне побуне у Немачкој. Током овог периода револуционарног превирања у Немачкој, социјалдемократи предвођени Фридрихом Ебертом (1871-1925) дошли су на власт без било какве намере да наставе у смеру прелаза у социјализам. Уместо тога, они су наредили убиство Розе Луксембург, Карла Либкнехта и других комуниста по кратком поступку на лицу места. Они су оптужили комунисте за угрожавање уставног поретка током устанка спартакиста у Берлину јануара 1919. године. Роза и Карл су сматрали да је овај устанак грешка (Hettman, 1980:308), али нису се двоумили да подрже покушај збацивања владе. Они су, наиме, били свесни да се критична маса радника у другим деловима Немачке није побунила.

Опортунистичке вође једне од најбројнијих социјалдемократских партија угушиле су устанак комуниста шаљући фрајкоре, паравојне трупе под покровитељством владе, састављене углавном од ветерана из Првог светског рата. Ови одреди смрти ${ }^{13}$ заробили су и по кратком поступку погубили Розу, Карла и друге комунисте. потврђујући постојање дубоких расцепа између револуционарног и реформистичког крила у оквиру широко схваћено лево оријентисаних покрета.

У својем последњем тексту пред смрт Пореgак је ирреолаgао у Берлину (јануар 1919/1999), упркос неуспеху Новембарске револуције 1918. године, Роза као прави револуционар узвикује: „Ви луди лакеји! Ваш 'поредак' је изграђен на песку. Сутра ће револуција устати поново, супротстављајући своје оружје, и на ваш ужас она ће прокламовати уз звуке труба: Ја сам била, ја јесам, ја ћу бити!” (https://www.marxists. org/archive/luxemburg/1919/01/14.htm).

Роза је била у праву када каже да руководство СДП, које је инсистирало на изборним победама и учешћу у буржоаском парламенту, очигледно није пронашло мирнији пут као социјализму. Насупрот томе, оно је утрло пут две деценије касније најреакционарнијој контрареволуцији која је икад виђена - националном социјализму. Не треба да се заваравамо да овакви догађаји из прошлости више нису могући захваљујући савременим уставима који бране демократске институције (Gürgen: 25/01/2019).

13 У многим земљама, посебно у Латинској Америци, државно насиље и данас коегзистира са паравојскама које врло личе на фрајкоре у Немачкој после Првог светског рата, који су погубили Розу Луксембург, Карла Либкнехта и друге комунисте. У Колумбији, на пример, држава и паравојно насиље које је предводила милитаристичка криминална влада Ивана Дјуке изазвали су генерални штрајк 29. априла 2021. године. Првог маја 2021. стотине хиљада домородачких и црних народа су изашли на улице, углавном млади који су савладали страх. Влада је одговорила на протесте насиљем без преседана, убијајући десетине демонстраната, као да њихови животи ништа не значе, као животи људи у земљама са неком врста апартхејда, Палестинци у Израелу и Гази, домородачки народи у Колумбији, црнци у САД или људи из Магреба у Француској, кад год капитал врши свој злочин против народа и природног окружења (Zibechi, R. 2021, May 21). 
О неизбежности коначне кризе капитализма још једном

Роза Луксембург увек изнова инсистира на неизбежности коначне кризе капитализма у складу са марксистичком теоријом као што је она тумачи, за разлику од Бернштајна и ревизиониста који тврде да се капитализам довољно прилагодио да постане способан да избегне кризе. Видели смо да неки коментатори критикују Розу због економског детерминизма и политичког фатализма када пише о неизбежности слома капитализма. Ово је, међутим, прилично једнострана критика. Роза, наиме, увек изнова инсистира да социјалдемократи не треба да чекају да се антагонизми капитализма развију у коначну кризу него да стално агитују међу радним масама и помогну дугорочну оријентацију спонтано насталих масовних штрајкова са новим модалитетима самоорганизације као што су скупштине и совјети. Лево оријентисане партије тако нису циљ сам по себи, па уколико реформистичке партије без револуционарног ангажовања постану препрека револуционарној активности маса, оне морају да буду замењене револуционарним партијама.

Розин привидни фатализам, може се објаснити као потреба револуционара да издрже и остану упорни у свом циљу да збаце капиталистички начин производње револуционарним средствима масовног штрајка и оружаног преузимања политичке власти, у условима стабилизације капитализма под реакционарним војним, конзуервативним или реформистичким социјалдемократским владама.

Одсуство инсистирања опортунистичких социјалдемократа на тенденцији капитализма да пролази кроз све разорније кризе своди се на Бернштајнов аргумент да се капитализам довољно прилагодио да избегне коначну кризу и да стога представља вечити начин производње. Управо када реформисти као Бернштајн закључе на темељу дужих периода привидног одсуства кризе и класне борбе да капитализам више није склон кризама, кризе избијају увек изнова, услед отпора потлачених класа политици владајућих класа заснованој на потрази за профитом путем акумулације на основу одузимања средстава за проиузводњу, све од тзв. првобитне акумулације (Marx, K. 1977:t.21, 630-682; Harvey, 2004).

Садашњи период привидне стабилизације капитализма је истовремено повезан са противречностима и претњама империјалистичког рата у оквиру епохе историјске смене хегемонијске силе у светском систему капиталистичке привреде (Wallerstein, 1974). Нови хегемонијски поредак изгледа да се помера на Азију, а посебно је фокусиран на Кину ${ }^{14}$ (Naughton: 2014; Vratuša, 2018b) .

14 До сада се успон Кине није ослањао на масовну ратну привреду, али садашње владајуће класе хегемонијске силе у опадању, САД, вероватно ће одбити да сиђу са своје позиције без отпора. У контексту актуелности Розине РиР и њене преокупације транзицијом од капитализма ка социјализму, многи коментатори истичу да Кина није социјалистичка земља, него једна врста интервенционистичког државног капитализма (за разлику од неолибералног и милитаризованог државног капитализма САД) који поседује сложен сустем друштвене контроле и дигитални систем надзора. Евентуални успон кинеске верзије државног капитализма на позицију нове хегемонијске силе, неће, према критичарима, значајно побољшати перспективе социјалистичког преображаја садашњег светског система. Постоји, међутим, недавно спроведена студија Универзитета Харвард која је након 13 година истраживања, открила међу кинеским становништвом пораст подршке влади у 


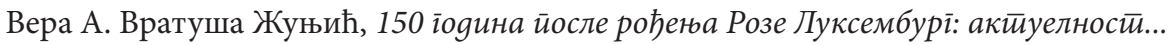

Сетимо се да су Маркс и Енгелс наглашавали да је резултат сталне класне борбе између израбљиване и израбљивачке класе то што се увек завршавала било револуционарним реконституисањем друштва, било заједничком пропашћу супротстављених класа (Marx, Engels. 1848/2010:32; Vratuša, 2018b).

Више од сто година пошто је Роза написала РиР и Јуниус йамфлети, више не постоји револуционарни друштвени контекст и значајан глобални раднички покрет дубоко прожет теоријом историјског материјализма, са утицајним левим крилом задојеним осећањем актуелности револуције. Роза Луксембург је у праву када наглашава да „можемо да растемо само кроз борбу, и управо усред борбе ми учимо како да се боримо" у актуелним борбама садашњице и сутрашњице ${ }^{15}$.

Џејмс Перон (1. јун, 2000) тврди да не постоји разлог за мишљење, да ако следимо савет данашњих реформистичких социјалиста, што је довело до самоуништења у Грчкој, Француској и Шпанији, да ћемо завршити са нечим веома различитим од варварског покоља који је преплавио Европу од 1914. надаље. Ништа битно се није променило у капитализму у протеклом периоду. Попут Розе. Перон тврди да тенденција капитализма да запада у кризе остаје. У ствари, кризе се продубљују и шире. Уколико би империјалистичка тензија између Кине и САД у неком тренутку у наредним деценијама избила у непосредан војни сукоб, последице за човечанство биле би још разорније него што је то био случај у Првом светском рату. А данас не треба да бринемо само због опасности од економске девастације и рата, него и због потенцијалне егзистенцијалне опасности због климатских промена.

Избор с којим се ми данас суочавамо није мање захтеван од избора који је Роза видела као конфронтацију човечанству на врхунцу Првог светског рата. Да ли ћемо дозволити да се продужава систем који гура човечанство из једне у другу катастрофу? Или ћемо се ујединити против система и његових бранитеља (укључујући оне који су наводно „на нашој страни”), и кренути револуционарним путем? Намеће се питање: да ли желимо само да освојимо нешто пријатељскију верзију капитализма, или ћемо се борити за друштво и привреду демократски и колективно контролисано од стране радника, у којем огромне могуђности и извори човечанства више неће да буду жртвовани на олтар тржишта, него ће да буду усмерени на обнову нашег

Пекингу са 86\% 2003 на 93\% 2016. године. Истраживачи закључују да Комунистичка партија Кине јесте на власти зато што је унапредила егзистенцију кинеског народа. Она стога наставља да ужива активну сагласност народа са влашћу Комунистичке партије, која је извукла из сиромаштва 800 милиона становника, док је средња класа порасла и сада броји 400 милиона становника (Korkodelović, 5. jul 2021: 23; Vratuša, 2018b).

15 Логичан закључак политике реформистичког и опортунистичког крила у оквиру СДПН јесте Програм из Годесберга (1959), у којем немачка СДП напушта своју приврженост марксизму и окреће своје обраћање гласачима средње класе, постајући велика кровна партија централне левице. Ова промена курса од „партије радничке класе у партију народа" доводи до тога да СДП експлицитно престаје да се залаже за социјализам марксистичке варијанте као што је то чинила Роза. Приватно власништво и принципи слободног тржишта су признати, а улога државе је сведена на опште послове који укључују планирање и усмеравање. Програм је заокружен афирмацијом значаја националне одбране и друштвено политичких захтева, као што су заједничко одлучивање на радном месту, једнакост за жене и побољшање могућности образовања. 
поремећеног односа са природом, и на обезбеђивање ствари које су нам потребне да бисмо живели пристојан живот?

Уколико желимо да превазиђемо варварство капитализма, онда потреба за врстом јасне, непоколебљиве револуционарне политике какву за пример даје живот и мишљење Розе Луксембург данас је хитан више него икада.

Аргументи данашњих реформиста неодољиво личе на Бернштајнове. Стога критика Розе Луксембург задржава актуелност за дебате које се воде на левици тренутно.

Заокрет ка централним десним партијама на власти резултирао је песимизмом у глобалном покрету за правду, што води повлачењу из активизма и огорченим унутрашњим борбама у оквиру оних који инсистирају било на политици заузимања државне власти или на политици културне трансформације, уместо инсистирања на обема истовремено (Wallerstein, February 15, 2019). Важна лекција коју можемо да извучемо из Розине $P u P$ јесте да инсистирамо на социјалистички оријентисаном садржају економских и друштвено-културних реформи.

\section{REFERENCES / ЛИTEPATУPA}

Bernstein, E. (1899/1907). The Pre-Conditions of Socialism and the Tasks for Social Democracy or Evolutionary Socialism (Die Voraussetzungen des Sozialismus und die

Aufgaben der Sozialdemokratie). Available at https://www.marxists.org/reference/ archive/bernstein/works/1899/evsoc/index.htm

Bottomore, T., Harris, L., Kiernan, V.G. \& Miliband, R. (1983). A Dictionary of Marxist Thought. Oxford: Basil Blackwell Publisher Limited

Evans, K. (2015). Red Rosa. Verso Books

Frederiksen, M. (23 March 2021). Reclaiming the revolutionary legacy of Rosa Luxemburg. Available at https://marxist.co.za/history-and-theory/324-reclaiming-the-revolutionary-legacy-of-rosa-luxemburg

“Godesberg Program in English". (1959). German History Documents. Available at https:// germanhistorydocs.ghi-dc.org/pdf/eng/Parties\%20WZ\%203\%20ENG\%20FINAL.pdf

Gürgen, M. (25/01/2019). 100 years since the killing of Rosa Luxemburg. Peščanik. Available at https://pescanik.net/100-godina-od-ubistva-roze-luksemburg/[In Serbian]

Harvey, D. (2004). The 'new' imperialism: accumulation by dispossession. Socialist

Register 40: 63-87. https://socialistregister.com/index.php/srv/article/view/5811\#. Ut2eEvszHID

Hedge Fund. (s.a.) Cambridge dictionary. Available at https://dictionary.cambridge.org/ dictionary/english/hedge-fund

Hettman, F. (1980). Rosa Luxemburg. Ein Leben für die Frieheit. Frankfurt

Korkodelović, B. (5. jul 2021). Dugi marš od 'crvenog broda'. Politika, 23

LeBlanc, P. (Nov. 17, 2019.) "Rosa Luxemburg and the actuality of revolution”. Links International Journal of Socialist Renewal. Available at http://links.org.au/rosa-luxemburg-actuality-revolution 
Вера А. Вратуша Жуњић, 150 іолина йосле рођења Розе Луксембурї: акйуелносй...

Lenin, V. I. (1918/1993). State and Revolution. The Marxist Theory of the State and the Tasks of the Proletariat in the Revolution. Available at https://www.marxists.org/archive Lenin/works/1917/staterev/

Luxemburg, R. (1900, 1908/1999) Reform or Revolution. Available at https://www.marxists. org/archive/luxemburg/1900/reform-revolution/index.htm

Luxemburg, R. (1905/2000). The Revolution in Russia. Available at https://www.marxists. org/archive/luxemburg/1905/02/08.htm

Luxemburg, R. (1913/on line version s.a.) Accumulation of Capital. Available at https://www. marxists.org/archive/luxemburg/1913/accumulation-capital/index.htm

Luxemburg, R. (1915/on line version s.a.) The Accumulation of Capital - An Anti-Critique. Available at https://www.marxists.org/archive/luxemburg/1915/anti-critique/index. htm

Luxemburg, R. (1915b/1996.) Junius Pamphlet. The Crisis of German Social Democracy. Available at https://www.marxists.org/archive/luxemburg/1915/junius/index.htm

Luxemburg, R. (1918/1999). The Russian Revolution. Available at https://www.marxists. org/archive/luxemburg/1918/russian-revolution/index.htm

Luxemburg, R. (1919/1999). Order Prevails in Berlin. Available at https://www.marxists. org/archive/luxemburg/1919/01/14.htm

Marx, Engels. (1848/2010). The Manifesto of the Communist Party. Available at https:// www.marxists.org/admin/books/manifesto/Manifesto.pdf

Naughton, B. (8 August 2014). The Chinese Economy: Transitions and Growth. Available at https://books.google.com/books?id=BZv6AQAAQBA]\&printsec=frontcover\&d$\mathrm{g}=$ The+Chinese+Economy:+Transitions+and+Growth\&hl\#v=onepage\&g\&f=false Google books.

Ontiveros, E. (2019). Do you know Red Rosa? Available at https://www.bbc.com/news/ wordd-46973330

Peron, J. (June 1, 2000). The Evolution of Capitalism. Why Did Europe Develop a System of Market Capitalism? Available at https://fee.org/articles/the-evolution-of-capitalism/ Scott, H. (2008). Introduction to Reform or Revolution. In H. Scott (ed.) The Essential Rosa Luxemburg: Reform or Revolution and The Mass Strike (18). Chicago, IL: Haymarket Books.

Thematic Issue Society \& COVID-19 (2020). Sociološki pregled 54 (3). https://scindeks. ceon.rs/issue.aspx?issue $=15240$ \&lang=en

Vratuša, V. (2018a). The review of Serbian translation of the handbook on social stratification in the BRIC countries - change and perspectives. Serbian state publisher of textbooks, Belgrade, 2014, 846pp. Sociološki pregled 52 (1), 346-354. DOI:10.59371 socpreg52-16763

Vratuša, V. (2018b) Manifesto of the Communist Party 170 Years After The First Edition: Introduction to the Thematic Issue of Sociološki pregled/Sociological Review. Sociološki pregled 52 (2), 415-429. DOI: 10.5937/socpreg52-18162

Vratuša, V. (2020a). Relevance of Lenin's State and Revolution for the theoretical preparation of Bolsheviks to politically organize the new wave of creative revolutionary praxis of the working masses on the eve of the October revolution. Sociološki pregled 54 (4), 1068-1094. DOI:10.5937/socpreg54-29706 
Vratuša, V. (2020b) Actuality of Engels' text Development of socialism from utopia to science. In M. Višić, M. Artić (eds.) 200 years of Friedrich Engels. Zagreb: Durieux. Available at https://www.academia.edu/50007002/Actuality_of_Engels_text_Development_of_socialism_from_utopia_to_science [In Croatian]

Wallerstein, E. 1974. The Modern World System I. New York: Academic Press

Wallerstein, February 15, 2019 Commentary No. 491, "How to fight a class struggle". Available at https://iwallerstein.com/how-to-fight-a-class-struggle

Zibechi, R. 2021, May 21. State power and society in Latin America: an interview with Raul Zibechi. Roar Magazine: People \& Power. Available at https://roarmag.org/categories/ people-power/ 